\title{
DESAIN PEMBELAJARAN LUAS SEGI BANYAK MENGGUNAKAN TANGRAM BERPETAK DI KELAS IV
}

\author{
Lia Puspasari' ${ }^{1)}$, Zulkardi' ${ }^{2}$, Somakim ${ }^{3)}$ \\ Guru SD Islam Az-Zahrah Palembang ${ }^{1)}$ \\ FKIP Universitas Sriwijaya ${ }^{2,3)}$ \\ Email ${ }^{1)}$ : belang_miauuu@yahoo.co.id \\ Email2): zulkardi@yahoo.com \\ Email3): somakim_math@yahoo.com
}

\begin{abstract}
ABSTRAK
Penelitian ini bertujuan (1) untuk mengetahui pemahaman siswa kelas IV Sekolah Dasar dalam menemukan konsep luas segi banyak menggunakan Tangram berpetak; (2) menghasilkan lintasan belajar bagi siswa melalui Tangram berpetak dalam pembelajaran luas segi banyak menggunakan pendekatan PMRI di kelas IV. Penelitian dilaksanakan di SD Islam Az-Zahrah Palembang yang melibatkan 26 orang siswa kelas IV. Metode yang digunakan adalah design research pembelajaran luas segi banyak menggunakan Tangram berpetak melalui tahap-tahap preparing for the experiment, teaching experiment, dan retrospective analysis. Penelitian ini menghasilkan Learning Trajectory yang memuat serangkaian proses pembelajaran dalam 3 aktivitas yaitu: (1) menentukan jenis bangun datar dan mempartisi bangun (menggunakan konteks berbagai pekerjaan); (2) menentukan luas dengan persegi satuan (menggunakan Tangram berpetak); (3) menemukan algoritma luas segi banyak. Hasil dari percobaan pembelajaran menunjukkan bahwa dengan pendekatan PMRI, Tangram berpetak berperan sebagai model yang mendorong siswa menemukan konsep luas segi banyak.
\end{abstract}

Kata Kunci: Luas segi banyak, Tangram berpetak, design research, PMRI

\begin{abstract}
This research is used for (1) knowing the level of understanding on fourth grade students of elementary school in finding polygon area concept through square-grid Tangram; (2) producing the learning trajectory for the student in learning polygon area through square-grid Tangram by using PMRI approach to the fourth grade students. This research is involving 26 students of fourth grade at Az-Zahrah Islamic Elementary school Palembang. The research is using design research methodology of learning polygon area through square-grid Tangram consist of preparing for experiment steps, teaching experiment, and retrsospective analysis. The result of the research is Learning Trajectory consist of the three learning process activities, which are: (1) determining the kinds of plane figure and plane partitioned (using many kinds of employment context); (2) determining the area of square unit (using square-grid Tangram); (3) finding the algorithm of polygon area. The result shown that by using PMRI approach, squaregrid Tangram is useful as a model to support the students in finding polygon concepts.
\end{abstract}

Keywords: Polygon area, Square-grid Tangram, design research, PMRI

\section{PENDAHULUAN}

Geometri merupakan cabang matematika yang diajarkan pada setiap jenjang pendidikan, baik pada jenjang pendidikan sekolah dasar hingga di perguruan tinggi. Geometri merupakan bagian matematika yang sangat dekat dengan siswa, karena hampir semua objek visual yang ada di sekitar siswa merupakan objek geometri (Safrina, Ikhsan, dan Ahmad; 2014).

Usiskin (1982) memberikan alasan 
mengapa geometri perlu diajarkan yaitu pertama, geometri satu-satunya bidang matematika yang dapat mengaitkan matematika dengan bentuk fisik dunia nyata. Kedua, geometri satu-satunya yang dapat memungkinkan ide-ide matematika yang dapat divisualisasikan, dan yang ketiga, geometri dapat memberikan contoh yang tidak tunggal tentang sistem matematika. Konsep-konsep geometri banyak digunakan dalam berbagai bidang pekerjaan, seperti dalam pekerjaan konstruksi bangunan, furniture, bahkan juga dalam bidang seni. Namun prestasi siswa Indonesia dalam bidang geometri mulai dari SD sampai perguruan tinggi masih rendah. Hasil penelitian Sarjiman (2001) tentang penguasaan matematika SD dari mahasiswa PGSD Prajabatan, menunjukkan bahwa geometri termasuk materi yang sulit untuk dikuasai.

Salah satu bagian geometri yang diajarkan di Sekolah Dasar adalah materi luas segi banyak. Luas segi banyak dapat ditentukan dari luas gabungan bangun datar. Penelitian tentang pembelajaran luas gabungan bangun datar sudah pernah dilakukan oleh beberapa peneliti sebelumnya, diantaranya Hariyanto (2010) yang menyatakan peningkatan hasil belajar luas bangun segi banyak sederhana melalui media pembelajaran konkrit.

PMRI (Pendidikan Matematika Realistik Indonesia) atau RME (Realistic Mathematics Eduacation) adalah teori belajar matematika yang dikembangkan di Belanda sejak awal 1970-an. Sebagai sebuah teori, RME memiliki filosofi dan karakteristik sendiri. PMRI atau RME menggabungkan pandangan tentang apa matematika, bagaimana siswa belajar matematika, dan bagaimana matematika harus diajarkan (Zulkardi, 2002). Menurut Ilma (2011), PMRI adalah salah satu pendekatan pembelajaran yang akan menggiring siswa memahami konsep matematika dengan mengkonstruksi sendiri melalui pengetahuan sebelumnya yang berhubungan dengan kehidupan sehariharinya, dengan menemukan sendiri konsep tersebut, maka diharapkan belajar siswa menjadi bermakna. Untuk itu diperlukan pendekatan PMRI dalam pembelajaran materi luas gabungan bangun datar di sekolah sehingga siswa mampu mengeluarkan pendapat, bertanya, dan mempresentasikan jawabannya.

Menurut Zulkardi dan Ilma (2010), pada pendekatan ini peran guru tak lebih dari seorang fasilitator, moderator atau evaluator sementara peran siswa lebih banyak dan aktif untuk berpikir, mengkomunikasikan argumentasinya, menjustifikasi jawaban mereka, serta melatih nuansa demokrasi dengan menghargai strategi atau pendapat teman lain.

Dalam membelajarkan konsep geometri, Hiele (1999) menegaskan bahwa untuk mengembangkan geometry thinking harus melalui rangkaian aktivitas yang dimulai dari permainan. Senada dengan hal tersebut, pendekatan PMRI pun menekankan adanya penggunaan konteks sebagai starting point dalam pembelajaran matematika seperti permainan tradisional, cerita rakyat, dan bentuk formal matematika bisa digunakan sebagai konteks atau masalah realistik sehingga siswa mampu mengeluarkan pendapat, bertanya, dan mempresentasikan jawabannya.

Penelitian yang akan dilakukan oleh peneliti berkaitan dengan konteks Tangram berpetak yang berhubungan dengan bentuk pada suatu pekerjaan pada materi luas segi banyak. Tangram adalah salah satu jenis puzzle yang paling populer di dunia. Tangram adalah suatu puzzle yang terdiri dari tujuh keping bangun datar yang disebut 'tans' (Wiratama, 2012). 
Metode tersebut telah digunakan beberapa peneliti, diantaranya Lisnani, Ilma, dan Somakim (2013) yang mendesain pembelajaran bangun datar menggunakan fable "dog catches cat" and puzzle tangram.

Berdasarkan kurikulum yang dikembangkan di tahun 2013 yang disebut dengan kurikulum 2013, pendekatan PMRI sangat cocok digunakan. Hal ini disebabkan karena pada kurikulum 2013 terdapat pendekatan saintifik yang dalam pembelajarannya meliputi mengamati, menanya, mengumpulkan informasi/ mencoba, mengolah informasi/mengasosiasi, dan mengkomunikasikan.

Berdasarkan uraian tersebut, peneliti akan mendesain dan mengembangkan Hypothetical Learning Trajectory (HLT) berupa Tangram berpetak yang merupakan langkah awal dalam pembelajaran luas segi banyak, kemudian menggunakan pendekatan PMRI dan diterapkan di kelas IV.

Adapun tujuan penelitian ini adalah (1) untuk mengetahui pemahaman peserta didik kelas IV Sekolah Dasar dalam menemukan konsep luas segi banyak dengan menggunakan Tangram berpetak; (2) menghasilkan lintasan belajar bagi siwa melalui Tangram berpetak dalam pembelajaran luas segi banyak menggunakan pendekatan PMRI di kelas IV.

Materi luas segi banyak akan dipetakan ke dalam kurikulum 2013. Pemetaan menghitung luas segi banyak di kelas IV dalam kurikulum 2013 adalah dengan tema berbagai pekerjaan dan sub tema pekerjaan orang tuaku. Kegiatan pembelajarannya bereksplorasi tentang luas bangun gabungan. Kompetensi yang dikembangkan adalah: 1) Sikap: cinta lingkungan, rasa ingin tahu dan teliti; 2) Pengetahuan: Pekerjaan, perkembangan teknologi, pelestarian lingkungan, luas, dan keliling bangun gabungan, pertanyaan; 3) Keterampilan: Mencari informasi, menghitung, memprediksi, menganalisis, membandingkan dan menyimpulkan. Kompetensi Dasar pada pembelajaran ini yaitu: (1.14) Menentukan hubungan antara satuan dan atribut pengukuran termasuk luas dan keliling persegi; dan (4.9) Mengembangkan dan membuat berbagai pola numerik dan geometris. Sedangkan indikator pembelajarannya adalah (1.14.1) Menentukan luas dari segi banyak dengan menggunakan satuan petak (satuan persegi) dan (4.9.1) Mengembangkan dan membuat berbagai pola bangun segi banyak dengan satuan petak (satuan persegi).

Pada penelitian ini, konteks yang digunakan adalah Tangram. Tangram adalah suatu puzzle yang terdiri dari tujuh keping bangun datar yang disebut 'tans'. Bentuk tujuh keping Tangram tersebut terlihat pada Gambar 1.

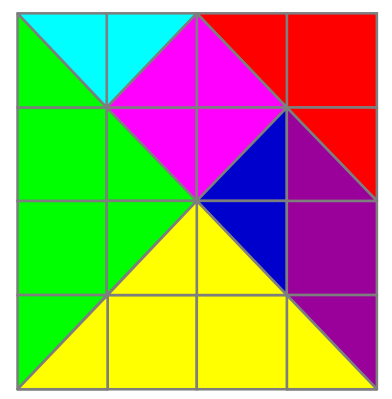

Gambar 1. Bentuk tujuh keping Tangram 
Dengan memindah-mindahkan ketujuh kepingan yang ada, kita dapat menciptakan berbagai bentuk yang sangat banyak. Ini adalah awal mula/dasar untuk mengerti akan luas (area). Model permainan Tangram digunakan dengan cara merangkaikan potongan Tangram dengan menempelkan bagian sisi yang sama panjang sehingga terbentuk bangun geometri yang dikehendaki.

Penyesuaian permainan Tangram bagi siswa adalah menyusun ketujuh keping Tangram menjadi segi banyak-segi banyak konvek. Terdapat 13 bentuk yang mungkin terdiri dari 1 segitiga, 6 segiempat, 2 segilima, dan 4 segienam. (Sobel dan Maletsky, 2004).

Penelitian yang dilakukan ini menggunakan pendekatan PMRI. Menurut Freudenthal dalam Gravemeijer (1994) dalam pembelajaran RME terdapat tiga prinsip, yaitu: 1) Guided reinvention and progressive mathematizing; 2) Didactical phenomenology; dan 3) Selfdeveloped models.

PMRI mempunyai lima karakteristik yang sesuai dengan karakteristik RME (de Lange, 1987; Treffers, 1991; Gravemeijer, 1994; Zulkardi, 2002), yaitu: 1) Menggunakan masalah kontekstual; 2) Menggunakan model atau jembatan dengan instrumen vertikal; 3) Menggunakan kontribusi siswa; 4)
Interaktivitas; dan 5) Terintegrasi dengan topik pembelajaran lainnya.

Adapun teori yang mendukung penelitian ini adalah teori Van Hiele. Teori van Hiele menjelaskan perkembangan berpikir siswa dalam belajar geometri akan melalui lima tahap (Usiskin, 1982; van de Walle, 2008; Rizkianto, 2012; Abdullah \& Zakaria, 2012), yaitu: 1) Tahap 0 (visualisasi); 2) Tahap 1 (analisis); 3) Tahap 2 (deduksi informal); 4) Tahap 3 (deduksi); dan 5) Tahap 4 (ketepatan).

\section{METODE}

Penelitian ini menggunakan metode penelitian design research yang melalui tiga tahap, yaitu preparing for the experiment, teaching experiment dan retrospective analysis. Dasar penelitian ini adalah dugaan pembelajaran di kelas sehingga menghasilkan lintasan belajar. Dugaan tersebut dianalisis lalu didesain kembali dan direvisi kemudian di implementasikan lagi (Gravemeijer dan Cobb, 2006).

Hal ini menunjukkan bahwa terdapat siklus proses yang berulang dari eksperimen pemikiran (thought experiment) menuju eksperimen pembelajaran (intruction experiment) (Gravemeijer, 1994). Proses siklik bisa dilihat seperti yang ditunjukkan oleh Gambar 2.

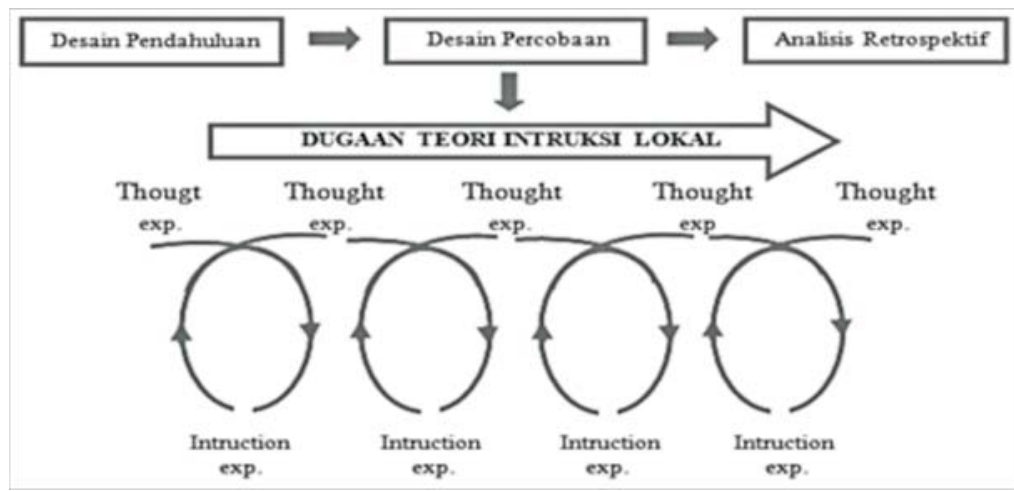

Gambar 2. Proses siklik dalam design research

Lia Puspasari, dkk. Desain Pembelajaran Luas Segi Banyak Menggunakan Tangram Berpetak di Kelas IV 
Adapun subjek dari penelitian ini untuk: tahap pilot experiment adalah sebanyak 6 orang siswa yang terbagi menjadi 3 kemampuan, yaitu tinggi, sedang dan rendah, dan pada tahap teaching experiment di kelas IV Tabligh SD Islam Az-Zahrah sebanyak 26 orang.

Tahap-tahap pelaksanaan penelitian ini, yaitu:

1) Preparing for the Experiment (Desain Pendahuluan)

Pada tahap ini dilakukan kajian literatur mengenai materi pembelajaran yaitu luas segi banyak, Tangram, PMRI, kurikulum 2013, dan design research sebagai dasar perumusan dugaan strategi awal siswa dalam pembelajaran luas segi banyak. Kemudian, peneliti akan melakukan wawancara dengan beberapa siswa untuk dijadikan informasi mengenai sejauh mana pemahaman siswa yang berkaitan dengan materi prasyarat pembelajaran luas segi banyak. Hasil tersebut akan digunakan peneliti sebagai bahan dalam mendesain hypothetical learning trajectory (hipotesis lintasan belajar), yaitu mengurutkan dugaan mengenai strategi siswa dan perkembangan berpikir dari siswa dan prediksi jawaban yang akan muncul. Dugaan ini bersifat dinamis sehingga dapat disesuaikan dengan reaksi siswa dalam belajar dan direvisi selama teaching experiment.

2) The Design Eksperiment (Desain Percobaan)

Pada tahap ini, uji coba desain dilakukan secara bertahap. Pada siklus pertama yaitu pilot experiment untuk mengujicobakan HLT yang telah dirancang pada siswa dalam kelompok kecil guna mengumpulkan data dalam menyesuaikan dan merevisi HLT awal untuk digunakan pada tahap teaching experiment nantinya. Dalam penelitian percobaan ini, peneliti akan berperan sebagai guru model agar HLT yang telah didesain dapat mencapai sasaran sesuai dengan tujuan pembelajaran. Hasil diskusi dengan guru dan wawancara dengan siswa akan digunakan sebagai bahan pertimbangan dalam memperbaiki HLT.

Pada siklus kedua, yaitu teaching experiment atau percobaan mengajar merupakan tahap inti dari design research karena pada tahap ini, HLT yang telah didesain atau dirancang dan diperbaiki sebelumnya akan diujicobakan di kelas sebenarnya yang menjadi subyek penelitian. Hasil dari tahap ini akan digunakan untuk menjawab masalah dalam penelitian ini. Guru model bertindak sebagai pengajar dan peneliti melakukan observasi terhadap aktivitas pembelajaran yang merupakan kemampuan pemahaman matematika siswa.

Selama proses berjalan, konjektur atau dugaan-dugaan/ide-ide dapat dimodifikasi sebagai revisi local instructional theory untuk aktivitas berikutnya.

\section{3) Retrospective Analysis}

Data yang diperoleh dari tahap teaching experiment dianalisa dan hasil analisa ini digunakan untuk merencanakan kegiatan dan mengembangkan rancangan kegiatan pada pembelajaran berikutnya.Tujuan dari retrospective analysis secara umum adalah untuk mengembangkan local instructional theory. Pada tahap ini, HLT dibandingkan dengan pembelajaran siswa yang sebenarnya untuk menginvestigasi serta menjelaskan bagaimana siswa dapat mengeneralisasi dari serangkaian aktivitas yang diberikan menuju ke konsep menghitung luas segi banyak dengan Tangram berpetak. Di samping itu, HLT juga dibandingkan dengan data-data yang dihasilkan untuk mendeskripsikan perkembangan strategistrategi yang digunakan siswa dan proses berpikir siswa. 
HASIL

Proses pembelajaran yang berlangsung terdiri dari beberapa aktivitas. Sebelum dan sesudah aktivitas dilakukan tes awal dan tes akhir guna mengetahui kemampuan pemahaman konsep peserta didik. Adapun aktivitas yang dilakukan adalah sebagai berikut:

\section{a. Aktivitas 1}

Menentukan jenis bangun datar dan mempartisi bangun menjadi beberapa bangun datar dari suatu profesi/ pekerjaan

Aktivitas siswa yaitu memperhatikan permukaan bangun yang berkaitan dengan suatu jenis profesi/pekerjaan dan mendiskusikannya secara berkelompok untuk menentukan jenis-jenis bangun datar yang terlihat dan membuat partisi bangun yang berkaitan dengan suatu pekerjaan menjadi beberapa bangun datar yang telah mereka ketahui.

Tujuan dalam pembelajaran ini adalah siswa dapat mengenal bangun datar dan mempartisi suatu bangun dari suatu pekerjaan menjadi beberapa bangun datar.

Hasil aktivitas yang dilakukan siswa adalah menentukan jenis bangun datar pada permukaan bangun yang berkaitan dengan pekerjaan dan dapat membuat partisi suatu bangun menjadi beberapa bangun datar. Hal ini dapat dilihat dari hasil kerja siswa pada Gambar 3. dan Gambar 4. berikut:

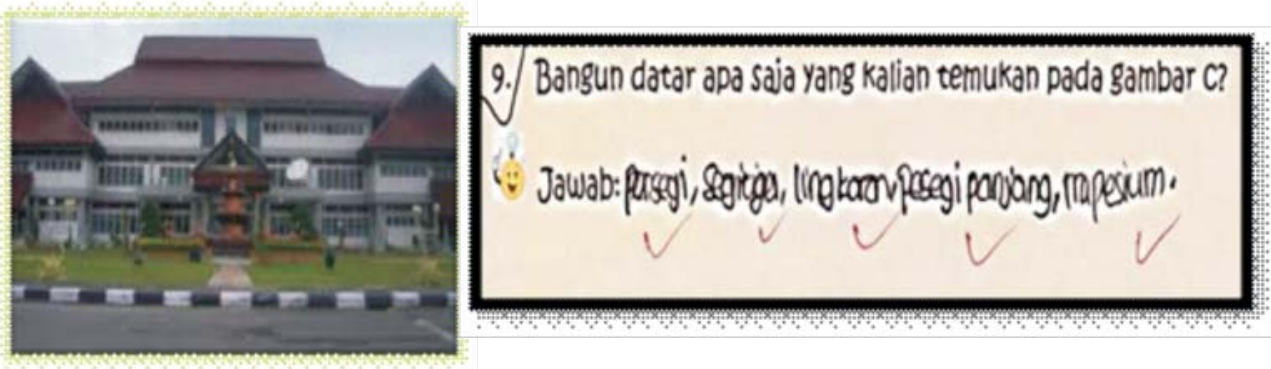

Gambar 3. Menentukan Jenis Bangun Datar

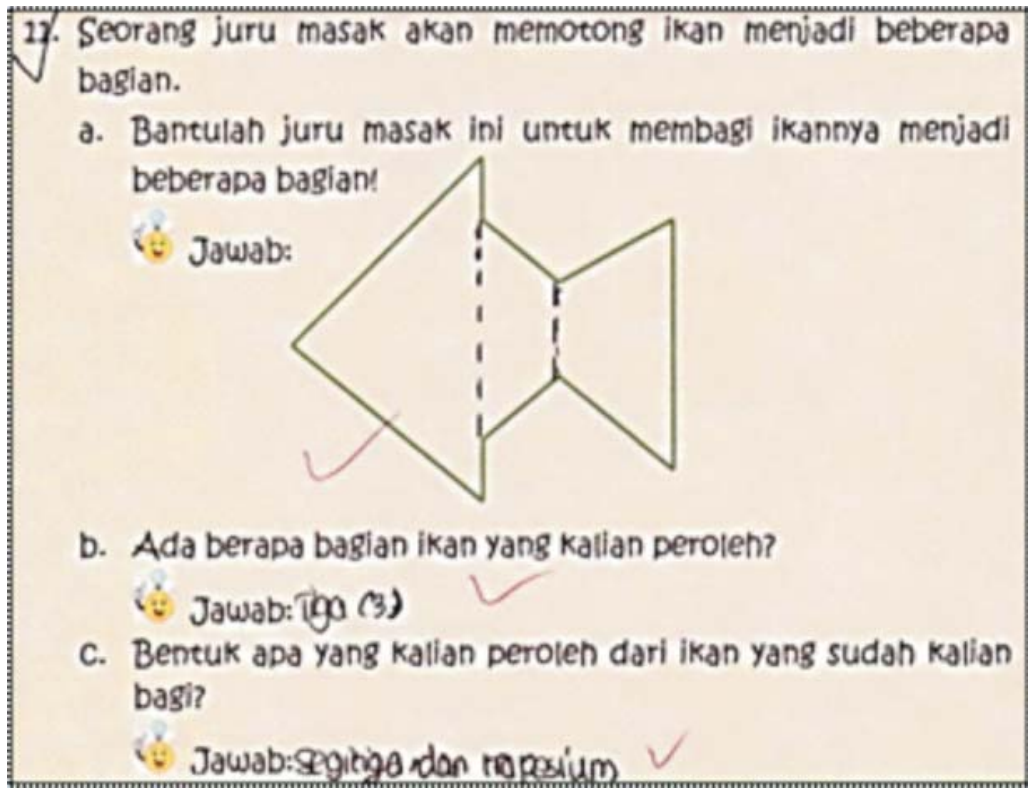

Gambar 4. Mempartisi Bangun

Lia Puspasari, dkk. Desain Pembelajaran Luas Segi Banyak Menggunakan Tangram Berpetak di Kelas IV 


\section{b. Aktivitas 2}

Menentukan luas dengan satuan persegi pada keping-keping Tangram.

Aktivitas siswa yaitu siswa diarahkan untuk menemukan jumlah satuan petak dari masing-masing keping Tangram berpetak dan menghitung jumlah satuan petak dari susunan gabungan keping Tangram berpetak yang mempunyai bentuk berbeda tetapi memperoleh hasil luas yang sama.
Tujuan dari pembelajaran ini adalah siswa dapat menentukan jumlah satuan petak pada masing-masing keping Tangram, sehingga dapat menghitung luas gabungan dari susunan keping-keping Tangram.

Hasil aktivitas yang dilakukan siswa secara berkelompok dengan menghitung jumlah petak satuan persegi pada keping Tangram dapat dilihat dari hasil kerja siswa pada Gambar 5. berikut:

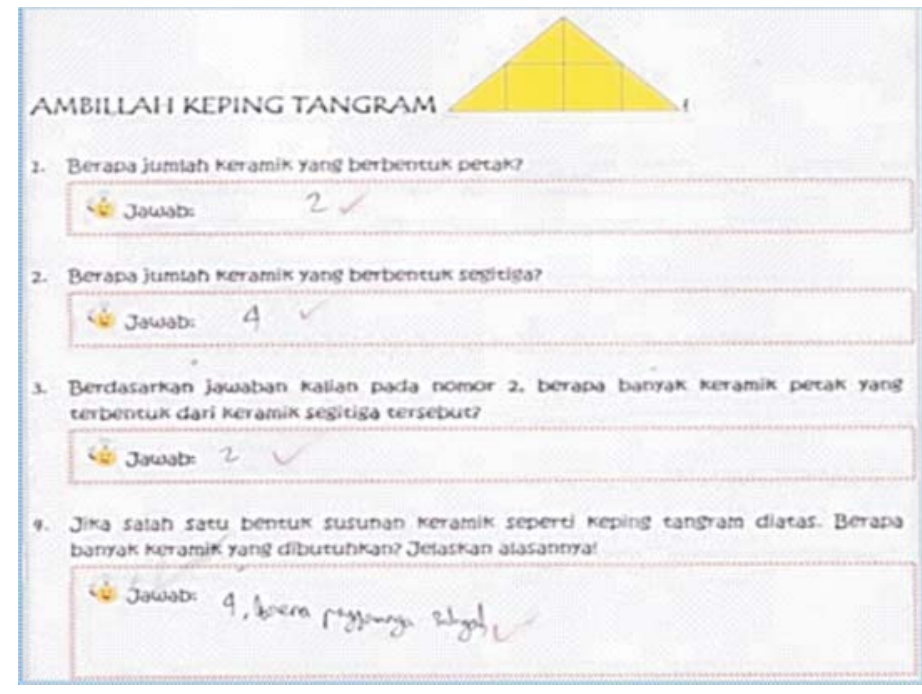

Gambar 5. Menghitung jumlah petak keping Tangram

Setelah siswa selesai menentukan jumlah satuan petak/persegi pada keping Tangram, siswa menyusun ketujuh keping Tangram menjadi suatu bentuk baru yang menyerupai gambar yang terdapat pada

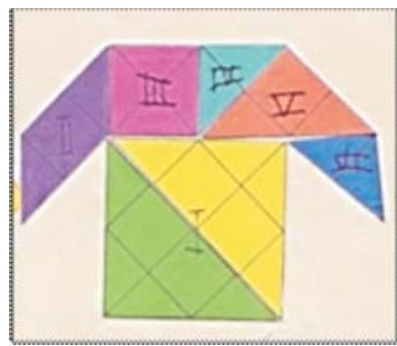

\section{Gambar 6.Hasil Kreativitas Susunan Keping Tangram Kelompok 2}

Pada Gambar 6. terlihat srategi siswa dalam menghitung bangun I dengan menggabungkan 2 keping Tangram yang berbentuk segitiga. soal. Setelah disusun, siswa menempel dan menghitung satuan petak/persegi pada bangun tersebut. Salah satu hasil jawaban siswa yaitu pada kelompok 2 terlihat pada Gambar 6. berikut:

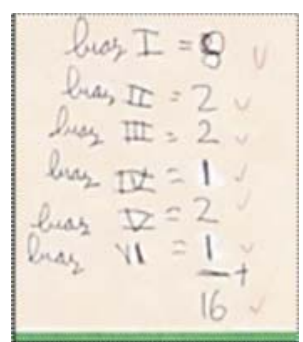

Selanjutnya siswa berkreativitas membuat susunan gabungan keping Tangram berpetak menjadi bentuk lain yang masih berkaitan dengan suatu pekerjaan. 
Hasil kreativitas siswa tersebut terlihat pada

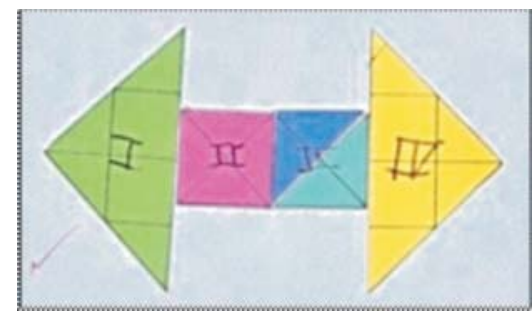

Gambar 7. berikut:

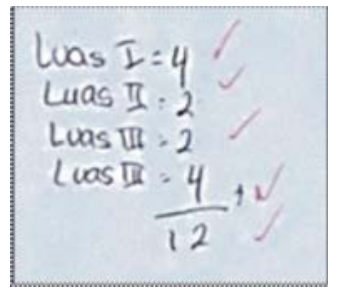

\section{Gambar 7. Kreativitas Siswa Menyusun dan Menghitung Luas Gabungan Keping Tangram}

Pada Gambar 7. di atas, siswa tidak menyusun semua keping Tangram, siswa hanya menggunakan 4 keping untuk membentuk suatu bangun baru yang berkaitan dengan jenis pekerjaan.

Akan tetapi, siswa telah menghitung luas dari bangun tersebut dengan benar. Hal ini terlihat dengan cara mereka membagi keping dengan memberi nomor dan menghitung pada masing-masing keping Tangram kemudian menjumlahkannya. Jawaban siswa tersebut sudah menunjukkan bahwa siswa telah memahami cara menghitung luas segi banyak suatu bangun, karena siswa menyatakan luas bangun yang mereka bentuk merupakan gabungan dari beberapa bangun datar.

Aktivitas permainan menyusun dan menghitung petak satuan pada keping Tangram dilakukan untuk mengingatkan siswa kembali dalam menentukan luas suatu bangun datar, sehingga akan mempermudah siswa dalam menghitung luas segi banyak suatu bangun.

\section{c. Aktivitas 3}

Algoritma Luas Segi Banyak.

Aktivitas siswa dalam pembelajaran ketiga ini mengamati gambar bangun yang mempunyai bentuk dan ukuran yang sama tetapi mempunyai partisi yang berbeda. Siswa menghitung masing-masing bangun tersebut dan membandingkan hasilnya. Setelah itu, siswa membuat sendiri partisi pada bangun segi banyak yang terdapat pada soal di LAS 3 dan menghitung luas bangun tersebut. Dengan urutan aktivitas yang telah dilakukan siswa menyimpulkan langkah-langkah menghitung luas segi banyak.

Tujuan pembelajaran pada aktivitas ini adalah siswa dapat menentukan cara menghitung luas segi banyak.

Hasil aktivitas siswa dari mengamati bangun dan menghitung luas masing-masing bangun yang terdapat pada LAS 3 terlihat pada Gambar 8. berikut:

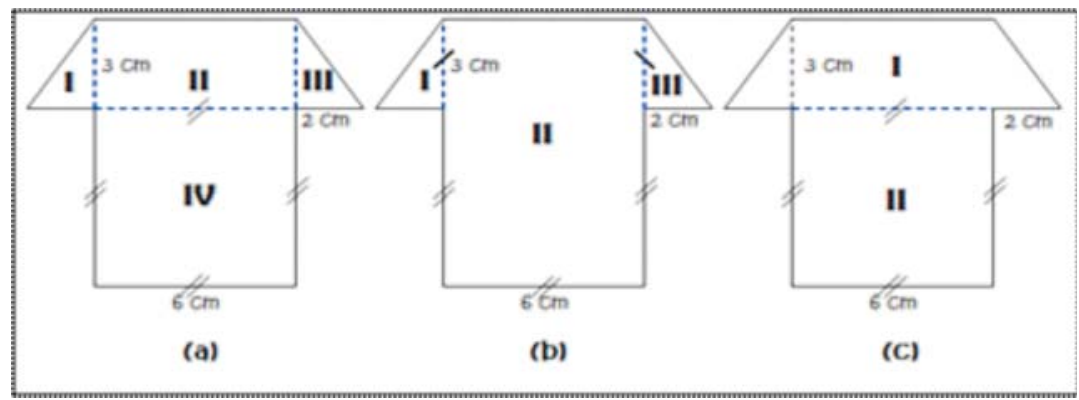

Gambar 8. Bangun Yang Diamati Siswa Pada Aktivitas 3

Lia Puspasari, dkk. Desain Pembelajaran Luas Segi Banyak Menggunakan Tangram Berpetak di Kelas IV 
Hasil yang diperoleh dari aktivitas ini adalah siswa dapat menentukan bahwa luas segi banyak yang mempunyai bentuk dan ukuran yang sama tetapi dengan partisi yang berbeda menghasilkan luas yang sama besar. Hal ini terlihat pada Gambar 9. berikut:

\begin{tabular}{|c|c|c|c|c|c|}
\hline \multirow{2}{*}{ Gambar } & \multicolumn{4}{|c|}{ Luas Bagian } & \multirow{2}{*}{ Luas Total } \\
\hline & 1 & II & III & IV & \\
\hline (a) & $=\frac{\frac{a x t}{2}}{\frac{3 x^{2}}{2}}=\frac{6}{2}=3$ & $\begin{aligned} & P \times L \\
= & 6 \times 3 \\
= & 19\end{aligned}$ & 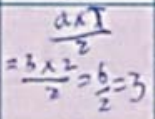 & $\begin{aligned} & 3 \times 3 \\
= & 6 \times 6 \\
= & 36\end{aligned}$ & $\begin{array}{l}3+18+3+36 \\
=60\end{array}$ \\
\hline (D) & $=\frac{a x t}{2}$ & $\begin{array}{l}=P \times l \\
=6 \times 9 \\
=54\end{array}$ & $=\begin{array}{c}\frac{a \sqrt{N T}}{2} \\
\frac{361}{2}=\frac{6}{2}=3\end{array}$ & - & $\begin{array}{l}3+54+3 \\
=60\end{array}$ \\
\hline (C) & $\begin{aligned} & \frac{(0+1) \times T}{2} \\
&= \frac{(6+10) \times 3}{2} \\
&=43^{2}=24\end{aligned}$ & $\begin{aligned} & 5 \times 5 \\
= & 6 \times 6 \\
= & 36\end{aligned}$ & - & $\longrightarrow$ & $\begin{aligned} & 2 y+36 \\
= & 60\end{aligned}$ \\
\hline
\end{tabular}

\section{Gambar 9. Hasil Jawaban Siswa dari Gambar yang Diamati}

Setelah siswa mengetahui bahwa luas suatu bangun yang mempunyai bentuk dan ukuran yang sama tetapi partisinya berbeda akan memiliki hasil yang sama. Siswa secara berkelompok menentukan partisi sendiri untuk menghitung luas segi banyak dari bangun yang diberikan. Gambar 10 (a). dan 10 (b). merupakan hasil strategi siswa dalam menghitung luas segi banyak suatu bangun.

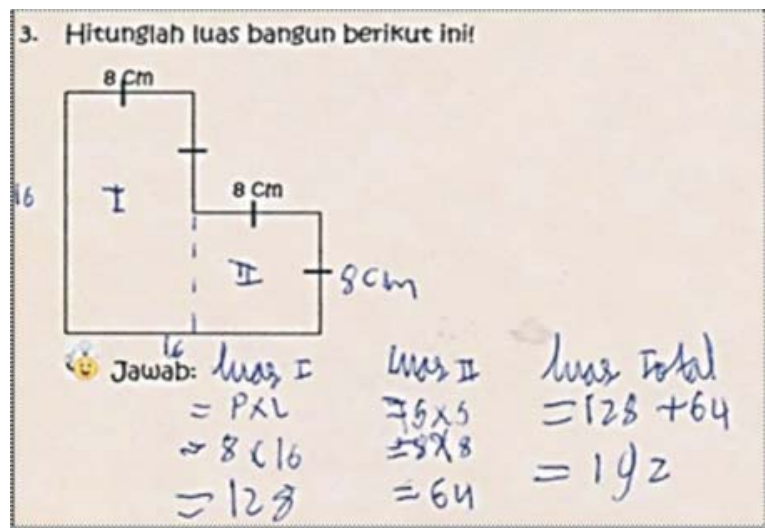

Gambar 10 (a). Strategi Siswa Mengitung Luas Segi Banyak

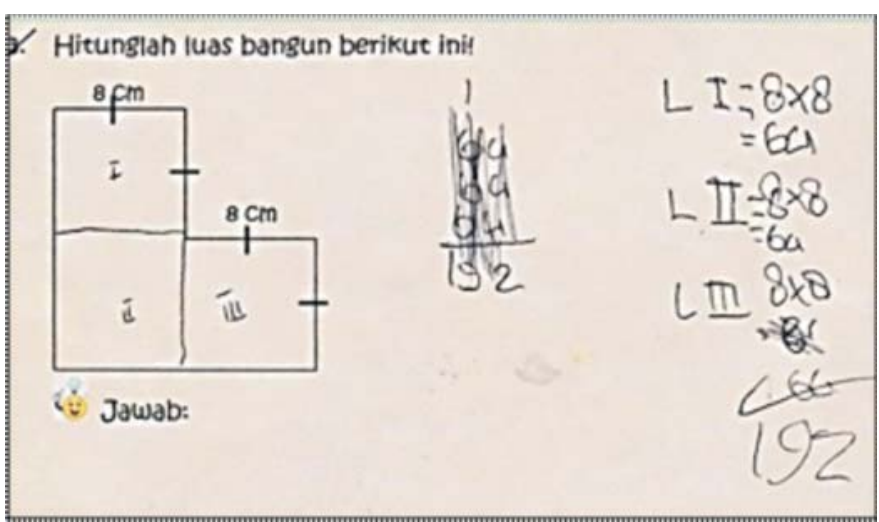

Gambar 10 (b). Strategi Siswa Mengitung Luas Segi Banyak 
Terlihat bahwa pada Gambar 10 (a) dan 10 (b) ada perbedaan pada partisinya. Pada Gambar 10 (a) siswa mempartisi menjadi 2 bagian, sedangkan Gambar 10 (b) mempartisi menjadi 3 bagian. Walaupun cara mempartisinya berbeda hasil yang diperoleh tetap sama.
Setelah melakukan serangkaian aktivitas, siswa menyimpulkan cara menentukan luas segi banyak suatu bangun. Gambar 11 berikut merupakan hasil kesimpulan yang mereka temukan.

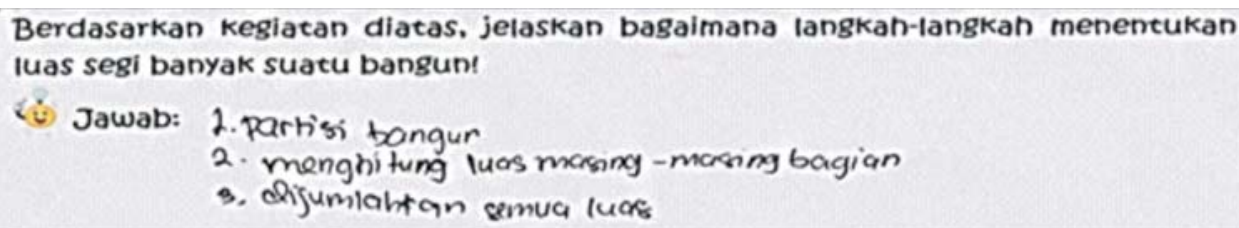

(i) Jawaban kelompok 3

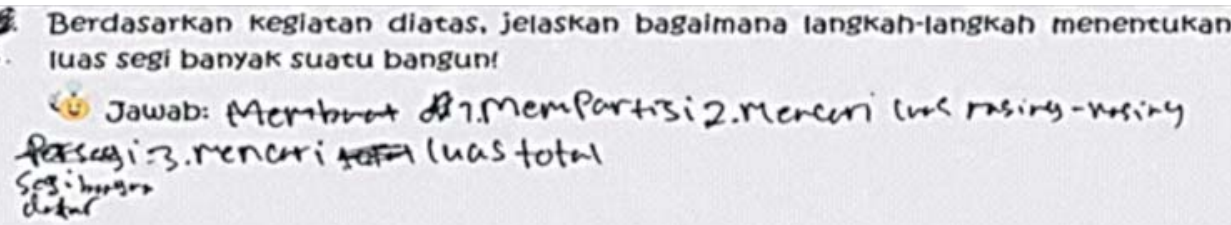

(ii) Jawaban kelompok 4

Gambar 11. Jawaban siswa untuk soal nomor 6

Pada Gambar 11 (i) dan (ii) diatas, menunjukan bahwa siswa sudah mampu menemukan cara menentukan luas segi banyak suatu bangun.

\section{PEMBAHASAN}

Berdasarkan hasil penelitian dan analisis retrospektif yang telah dilakukan, dapat dikemukakan bahwa pembelajaran ini telah didesain untuk melihat konteks yang mendukung pemahaman konsep siswa. Dari hasil design research yang telah dilakukan, diperoleh lintasan belajar luas segi banyak menggunakan Tangram berpetak dengan pendekatan PMRI. Selain itu diperoleh strategi-strategi pemikiran siswa dalam menyelesaikan materi luas segi banyak. Strategi tersebut merupakan dampak dari penerapan HLT yang telah didesain dan diujicobakan pada tahap pilot experiment kemudian direvisi sehingga dapat diterapkan pada teaching experiment yang menghasilkan LT. Untuk mendukung konteks tersebut, maka pendekatan PMRI berperan sangat besar dalam proses pembelajaran yang berlangsung lebih aktif dan efisien.

Aktivitas siswa terlihat sesuai dengan karakteristik PMRI. Karakteristik PMRI yang muncul dalam proses pembelajaran ini sejalan dengan aktivitas berpikir. Lima karakteristik PMRI (de Lange, 1987; Treffers, 1991; Gravemeijer, 1994; Zulkardi, 2002) yang merupakan adopsi dari RME pada hubungannya dalam pembelajaran ini akan dijelaskan sebagai berikut:

a) Menggunakan masalah kontekstual Menggunakan masalah kontekstual, yaitu matematika dipandang sebagai kegiatan sehari-hari manusia, sehingga memecahkan masalah kehidupan yang dihadapi atau dialami oleh siswa (masalah kontekstual yang realistik bagi siswa) merupakan bagian yang sangat penting. Peserta didik mengamati dan menganalisis

Lia Puspasari, dkk. Desain Pembelajaran Luas Segi Banyak Menggunakan Tangram Berpetak di Kelas IV 
bentuk bangun datar dan partisi dari jenis- Kegiatan ini terlihat pada Gambar 12 . jenis pekerjaan di sekitar lingkungan siswa. berikut:
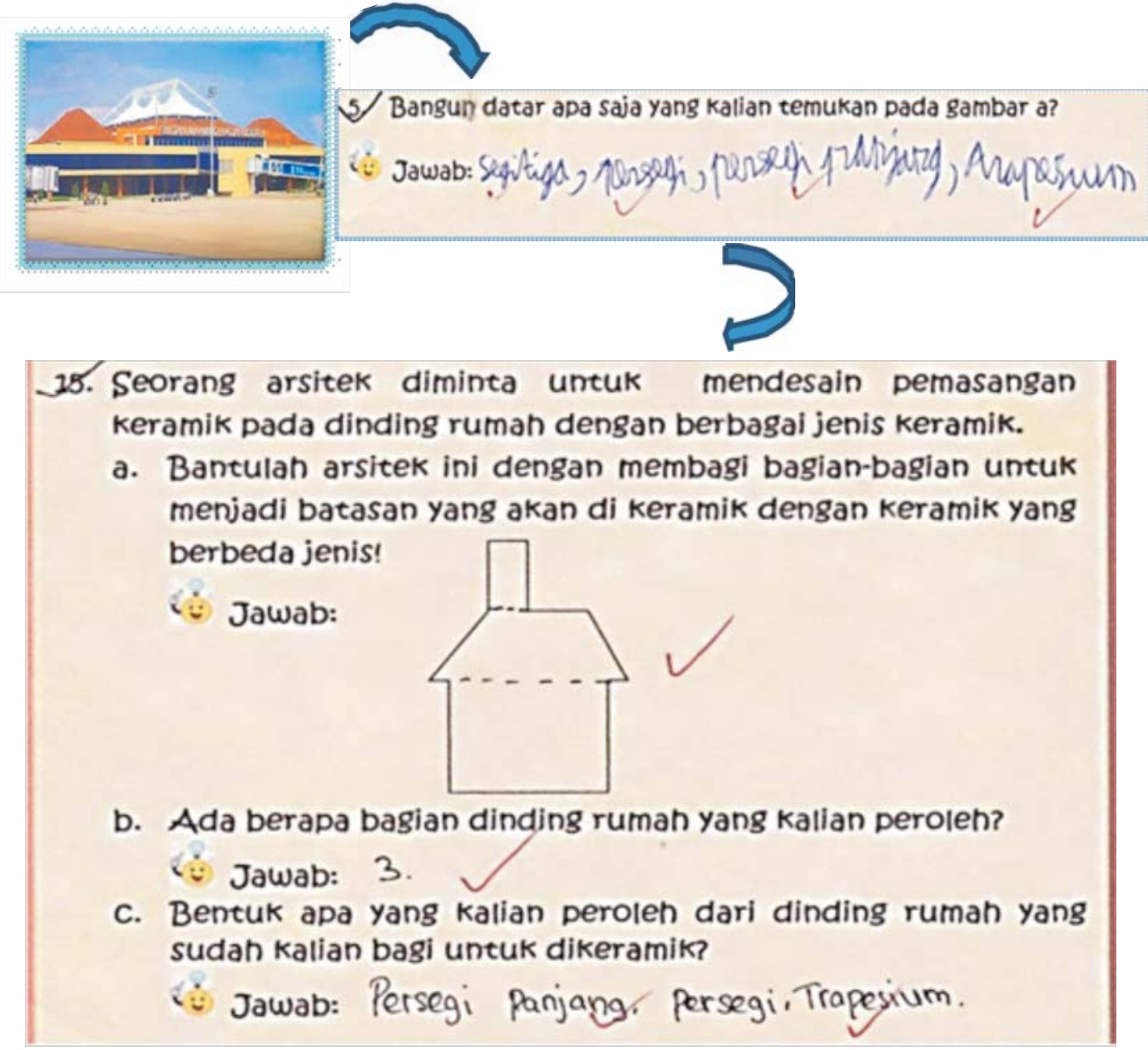

Gambar 12. Strategi siswa mengenal dan mempartisi bangun

b) Menggunakan model atau jembatan matematisasi horisontal). Siswa menghitung dengan instrumen vertikal

Menggunakan model, yaitu model belajar matematika berarti bekerja dengan matematika (alat matematis hasil satuan petak pada keping Tangram sehingga dapat menentukan luas dari gabungan bangun datar. Kegiatan ini terlihat pada Gambar 13. berikut:

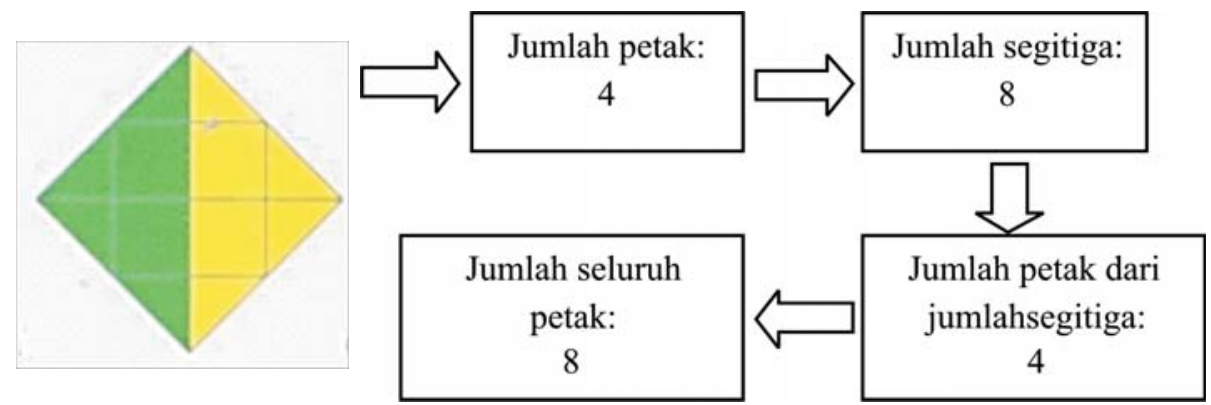

Gambar 13. Strategi siswa menggunakan model 
c) Menggunakan kontribusi siswa

Menggunakan hasil dan konstruksi siswa sendiri, yaitu siswa diberi kesempatan untuk menemukan konsep-konsep matematis, di bawah bimbingan guru. Siswa dengan bimbingan guru dapat menentukan langkah-langkah menghitung luas segi banyak. Kegiatan ini terlihat pada Gambar 14. berikut:

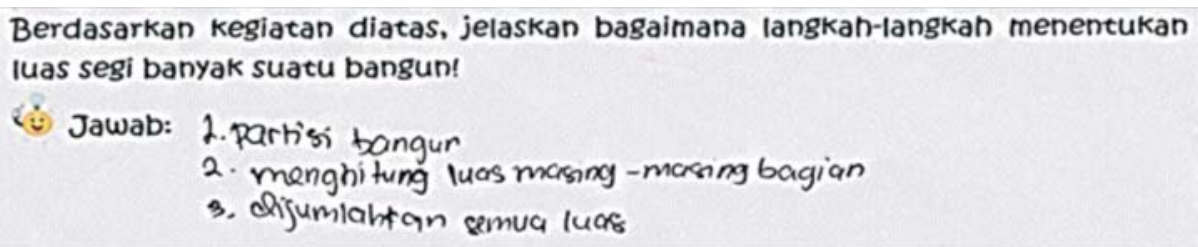

Gambar 14. Hasil siswa menemukan langkah menghitung luas segi banyak

\section{d) Interaktivitas}

Pembelajaran terfokus pada siswa. Proses pembelajaran yang terjadi terfokus pada siswa dengan melihat aktivitas yang dilakukan. Interaksi antara guru dan siswa terlihat pada saat proses pembimbingan kepada semua kelompok yang dapat dilihat dalam dialog-dialog pada hasil penelitian.

\section{e) Terintegrasi dengan topik pembelajaran lainnya}

Pada pembelajaran ini tidak terlepas dari konsep penjumlahan, perkalian, pembagian, dan perbandingan suatu benda.

\section{SIMPULAN}

Penggunaan pendekatan PMRI pada pokok bahasan luas segi banyak memiliki peranan penting dalam mengembangkan kemampuan komunikasi matematika siswa karena melalui pendekatan PMRI dapat dikembangkan aktivitas-aktivitas seperti menentukan jenis bangun datar, mempartisi suatu bangun, dan menghitung luas segi banyak yang di dalamnya diuraikan kegiatankegiatan mengamati, menanya, menalar, mencoba, dan mengkomunikasikan. Keping Tangram berpetak mempunyai kekuatan yang dapat merepresentasikan pikiran siswa dalam menentukan strategi yang digunakan. Pengembangan luas segi banyak menggunakan konteks yang nyata sehingga diharapkan dapat membantu dalam mengembangkan strategi berpikir siswa untuk mengemukakan ide atau gagasan dalam menyelesaikan masalah.

Dalam pembelajaran luas segi banyak menggunakan pendekatan PMRI lintasan belajar yang dilalui meliputi tiga aktivitas. Dari serangkaian aktivitas pembelajaran yang telah dilaksanakan dihasilkan lintasan. Lintasan belajar dalam penelitian meliputi aktivitas menentukan jenis bangun datar dan mempartisi bangun (menggunakan konteks berbagai pekerjaan berupa permukaan bentuk dari suatu ciri pekerjaan), menentukan jumlah satuan luas persegi (menggunakan keping Tangram berpetak untuk mendapatkan luas dari suatu masing-masing jenis bangun datar yang terbentuk dari suatu bangun segi banyak), dan menemukan algortima luas segi banyak (untuk mendapatkan luas segi banyak dapat diperoleh dengan mempartisi bangun menjadi beberapa bangun datar dan menghitung luas dari masing-masing partisi tersebut).

\section{DAFTAR PUSTAKA}

Abdullah \& Zakaria (2012). The Activities Based on Van Hiele's Phases of Learning Geometry in a Geometer's Sketchpad Environment: Experts'and Pre-Service Teachers' Views. Malaysia: 
Universiti Teknologi \& Universiti Kebangsaan Malaysia.

De Lange, J. (1987). Mathematics Insight and Meaning. Utrecht: OW \& OC.

Gravemeijer, K. (1994). Developing Realistic Mathematics Education. Utrecth: Technipress Culemborg.

Gravemeijer, K \& Cobb, P. (2006). Design Research From A Learning Design Perspective. Educational Design Research, 17-55.

Hariyanto, B. (2010). Upaya Peningkatan Hasil Belajar Luas Bangun Segi Banyak Sederhana melalui Media Pembelajaran Konkrit. J-TEQIP. 1 (1).

Hiele, P. (1999). Developing Geometric Thingking through Activities That Begin With Play. InTeaching Children Mathematic Journal. 5(6): 310-16.

Ilma, R. (2011). Improving Mathematics Communication Ability of Students in Grade 2 through PMRI Approach. Dalam Prosiding International Seminar and The Fourth National Conference on Mathematics Education 2011, Yogyakarta, tanggal 21 s.d. 23 Juli 2011, hal. 547-556. Universitas Negeri Yogyakarta.

Lisnani, Ilma R., \& Somakim. (2013). Desain Pembelajaran Bangun Datar Menggunakan Fable 'Dog Catches Cat' and Puzzle Tangram di Kelas II SD. Jurnal Kreano. 4(1) : 11-25.

Rizkianto, I. (2013). Constructing Geometric Properties Of Rectangle, Square, And Triangle In The Third Grade Of Indonesian Primary Schools. Jurnal IndoMS-JME. 4(2): 160-171.

Safrina K., Ikhsan M., \& Ahmad A. (2014). Peningkatan Kemampuan Pemecahan Masalah Geometri melalui Pembelajaran Kooperatif Berbasis Teori Van Hiele. Jurnal Didaktik Matematika. 1(1) : 10.
Sarjiman, P. (2001). Tingkat Kemampuan Mahasiswa PGSD dalam Menyelesaikan Soalsoal Matematika SD dan faktorfaktor yang Mempengaruhinya. Laporan penelitian, Lemlit UNY.

Sobel, M. A. \& Maletsky, E. M. (2004). Mengajar Matematika: Sebuah Buku Sumber Alat Peraga, Aktivitas, dan Strategi. Jakarta: Erlangga.

Treffers, A. (1991). Realistic mathematics education in the Netherlands 19801990. In L. Streefland (Ed.), Realistic mathematics education in primary school. Utrecht: CD-B Press/Freudenthal Institute.

Usiskin, Z. (1982). Van Hiele Levels and Achievement in Secondary School Geometry. (ERIC Document Reproduction Service No. ED 220288). Retrieved from ERIC database.

Van de Walle (2008). Matematika Sekolah Dasar dan Menengah: Pengembangan pengajaran. Jilid Pertama. Jakarta: Erlangga.

Wiratama, D. (2012). Tangrams: Puzzle Peningkat Kreatifitas. Tersedia di http:/ /dira89.blogspot.com/2012/07/handson-tangrams-puzzle-peningkat.html. Diakses tanggal 1 Mei 2014.

Zulkardi, (2002). Developing a learning environment on Realistic Mathematics Education for I ndonesian student teachers. Doctoral dissertation. Enschede: University of Twente.

Zulkardi \& Ilma, R. (2010). Pengembangan Blog Support untuk Membantu Siswa dan Guru Matematika Indonesia Belajar Pendidikan Matematika Realistik Indonesia (PMRI). Tersedia di http:/ /eprints.unsri.ac.id/5401. Diakses tanggal 3 September 2014. 